\title{
Globalization and the Challenges for Poverty Eradication and Development in Africa: The Nigerian Experience.
}

\author{
${ }^{1}$ Ogoh Augustine O., ${ }^{2}$ Orbunde Emmanuel \\ ${ }^{I}$ (B.sc, MPPA, M.sc) Department of Political Science Faculty of Art, Management and Social Sciences Federal \\ University, Dutsin-ma Katsina State Nigeria \\ ${ }^{2}$ (B.sc, M.sc) Department of Political Science Faculty of Art, Management and Social Sciences Federal \\ University, Dutsin-ma Katsina State Nigeria
}

\begin{abstract}
Of all social, economic and political phenomena, the most dominant trend in contemporary World system is globalization, which is being driven particularly by a new wind of information technology that is unparalleled in the history of humankind. Nation states have consistently intensified efforts towards engaging in business across national borders and constructing production and distribution networks on a global scale. Thus, the world today is a global village given the unprecedented level of inter-connectedness of political, economic, social and technological forces that permeate contemporary international system. This paper discusses the preponderance of a global environment which is strongly ingratiated in a system of interdependency, by a section of the international community especially Africa and the necessity for Nigeria, to take concrete steps to minimize the adverse effects of globalization while harnessing whatever may come its way that would enhance national development and poverty reduction. The paper concludes that Nigeria must embark on an overhaul as well as an entire restructuring and transformation of its political and economic superstructures in order to decisively confront contemporary economic challenges in the global arena.
\end{abstract}

Key words: Globalization, Development, Superstructure, Poverty Eradication, Interdependency

\section{Introduction}

“. . I saw firsthand the devastating effect that globalization can have on developing countries, and especially the poor within those countries. I believe that globalization - the removal of barriers to free trade and the closer integration of national economies - can be a force for good and that it has the potential to enrich everyone in the world, particularly the poor. But I also believe that if this is to be the case, the way globalization has been managed including the international trade agreements that have played such a large role in removing those barriers and the policies that have been imposed on developing countries in the process of globalization, need to be radically rethought." ( Joseph Stiglitz) It is challenging and startling having statement like this about globalization coming a former world bank chief Economist, winner of the Nobel laureate in Economics 2001 and former chairman of President Clinton's council of Economic advisor. Globalization is a phenomenon that is fast growing; both out of some natural as well as manmade efforts. The emergence of a globalized world stems from the natural development of life which is spurred by the Advancement of civilizations which are themselves occasioned by the overflow of technology in information and telecommunication. The internet, the global system for mobile communication (GSM), the telephony, the Satellite TV, the air transportation system, etc, have reduced the globe into a small but complex village. These factors have naturally narrowed the boundaries of otherwise very distant regions to very close neighbors. The New technologies have drastically reduced people's perceptions of communities (Mathews, 1997 in kegley \& Wittkopf, 1992:247). Remarkable political and economic issues that occur in distant lands such as America become issues in china in far away south-east Asia, Chile in South America and Nigeria in Africa thousands of miles across the Atlantic Ocean just in a matter of seconds. For instance, the financial crisis that has rocked the mortgage institutions in the US which has seriously affected the entire US economy is already negatively impacting the entire world, thus forcing nations across the globe to strategize and bring up remedial economic Approaches to prevent the breakdown of their respective economies. Even the southern countries are not left out in the challenges. In Nigeria, just as in many other African countries, the economic down turn has already exacerbated the state of health of ailing Nigerian stock market, causing the portfolio investors to withdraw their investments and stocks in the stock market. In fact, countries all over the world are considering bailouts in critical sectors of their economies in resistance to the global financial crises. This is the current reality of the Globalization phenomenon. Mark (1999) in Baylis and Smith(2001) has pointed out that: globalization - The process of continuing integration of countries in the world - is strongly underway in all parts of the world. Supported by accelerated pace of technological change, by price and trade liberalization, and by growing importance of supranational rules, globalization has exposed national economies to much more intense competition than ever 
before. Many decry the inability of third world nations in reaping the dividends of globalization. They insist that even

though most developing countries have been told to open up their economies, and receive development, they only ended up growing poorer. Despite the well publicized claims of export and income gains, nothing as yet is there to show for it (Khor, 2000:1). A society such as Nigeria, whose economic and social fabrics are rapidly being dislocated by extensive financial and trade liberalization, will surely lead to gross inequalities of wealth and opportunities with the ultimate results to heightened poverty in the land.

\section{What Then Is Wrong?}

What is the nature of the multilateral economic activities of the actors in this global village? Are the relationships mutually beneficial to all the actors? Are these bullies among the actors who are repressing the prospects for an even development of this village? Or are there actors, though richly endowed, merely gloating over non-issues and thus wasting their time on issues that have no potentials to enhance their growth and development? How can Nigeria eradicate poverty and develop in the fast globalizing world? These among other issues have been highlighted in this paper.

\section{Globalization: Concept, Nature And Processes}

The literature on the nature and processes of globalization is legend. See (Ake, 1981, 1995; Offiong 1980; Oniomode, 2000, Baylis and Smith 2003, Khor 2005, Obadan 2004, Ajayi 2004, Aina, 1996; Appadurai, 2001 Clark, 1999; Nabudere, 2000; Ninsin, 2000; Mittleman, 2000; Rugumamu, 1999; scholte, 2000; Tandon, 2000; (Akinboye 2008 www.globalization.icaap.org/content etc). Globalization is a phenomenon which cuts across entire world, and it means different things to different people. Scholars, policy analysts as well as leaders across the globe are polarized into two intellectual camps in their explanation of the concept. There are neoMarxist dependency school and the neo-liberal school. While the two schools both agree in principle that globalization encompasses the general integration of world's social, economic and political spheres into one borderless global village, they differ in their conceptualization of the driving force behind the phenomenon, its impacts and processes in the global economic system. To the neo-Marxist dependency school:globalization is the final conquest of capital over the rest of the world and that its "antecedents" and "uneven thesis "are explainable within the one-arm banditry and ethos of capitalism... this will continue to be so, irrespective of its aim at the transcendental homogenization of homogenization of political and socio-economic theory across the globe and its purported benefits to mankind..." (Akindele et al, http://www.unido.org/index.php?id o4502: 2002)Neo-Marxist scholars argue that, "asymmetry of power and interests of member states of the global village, as well as the lopsidedness in the rules of the game there-in, cannot benefit Africa and her people. ( Akindele et al, http://www.unido.org/index.php?id o4502: 2002). He further contends that this is so and would continue to be so because globalization is a new order of marginalization and decolonization in a "neo-neocolonial fashion", of the African continent. In this school of thought are scholars like Ake (1981, 1996); Amin, (2003), Frank, (1966) Akindele, (2002) offiong, (1980). The Neo-Marxist dependency theorists argue that globalization is the concluding stage of capitalism and it has rapidly wrecked havoc to the political economies of the third world countries and Africa in particular. Ayandiji (2005: iii) another neo-Marxist scholar, believes that "the embedded neo-colonizing exploits of globalization weaken rather than strengthen the economy. He further contends that it is a "force of inequality and marginalization which constitutes a dividing factor between the developed and developing countries for this Africa comes out or worst victims. To him, countries of Africa such as Nigeria, made enormous contributions to the global economy, it remains at the receiving end of the side effects rather than the gains of globalization - mounting debt profile, capital flight, collapse of local industries, galloping inflation, weak currency, over dependence on imported goods and services, mono-product economy (Onimode 2000). To Offiong, (1980:53) this situation is known as economic imperialism and it leads to dependency on the part of the developing world including Nigeria. If the Nigerian economy dependent on the world capitalist economy for advancement then, there cannot be hope for poverty eradication in Nigeria.

This is clearly against the celebrated view by the liberal school that globalization, more than anything else shapes the international economic relationship to favor Africa and other third world nations, and it gives them the opportunity to modernize and develop, thus implicitly globalization is a blessing to Africa and the rest of the third world countries. On the other hand the liberalist school opine that globalization has offered opportunities to African countries and the third world in general by liberalizing trade, foreign direct investment (FDIs), favorable trade policies through the Bretton Woods institutions (the IMF, World Bank and GATT/WTO) and giving of economic incentives to most developing countries by the advanced countries. The liberal scholars see the concept as a framework of complex and growing interdependence among nations. The global socio-political and economic integration is viewed in the context of inter dependencies which has restructured the world into a new and all inclusive social pattern. They associate globalization with economic liberalization as a policy option for the development of globalization as interdependent among nations. The 
global socio-political and economic integration is viewed in the context of their dependencies which has restructured the world into a new and all inclusive social pattern. They associate globalization with economic liberalization as a policy option for the development of the south through a process of free trade, investment and capital flows between countries. Scholars of globalization as interdependent have consistently maintained that globalization is the rational end point of human development and that is capable of impacting positively on the life of state actors that integrate their economies. In this perspective Africa and indeed Nigeria's problem is lack of commitment to modernization of their socio-economic and political ideals. Scholars in this camp include Rostow, WW (1966); Mchelland, D; Hagan, EE; Hoselitz, BF, in Offiong 1980: 23-43).

The position of the two camps is succinctly summarized by Kema, (http://findarticles.com/p/page.sb= Aboutproquest. 2008), that "there are some observers (liberal scholars) who believe that globalization has brought rapid prosperity to the underdeveloped countries, while others (neo-Marxist scholars) argue that globalization serves the needs of the metropolitan countries at the expense of the peripherical countries". But it is important to observe that Nigeria, and other African nations states who have actively undermined the growth of their economies, have more to blame than the global system. The fact that other third world countries such as India, Malaysia, Korea, and Botswana in Africa whose share of the so called "global malaise" is no less, yet are still ahead exposes the question of leadership and management. It can thus be concluded that the general consensus by scholars is that globalization essentially is the increasing interconnectedness and interdependence among the world's regions, nations, governments business, institutions communities, families and individual, as a result of the rapid advancement in information and communication technology. (Ake, 1981, 1996; Offiong, 1980, Obadan, 2004:3; Aluko 2004; Olomola 2004:131; Uwait 2004:129; Khor 2005; Amin 2003). There is no doubt that globalization has impacted differently on the two parts of the global system. While it strengthens the already developed advanced western countries, it marginalizes the peripheral economy of the Third World countries. Akinboye 2008).

\section{Poverty And Africa's Poverty Condition: A Conceptual Analysis}

Pope John II defined poverty as "a condition in which life is so limited by lack of food, malnutrition, illiteracy, high infant mortality and low life expectancy as to beneath any rational definition of human decency" (Ozughalu \& Ajayi 2003: 513). Poverty today means levels of living, characterized by low incomes, inequality, poor health and inadequate education; low level of productivity high rates of population growth and dependency burdens. (Todaro and Smith 2003:46). T o Ozughalu \& Ajayi (2003:513) these characteristics are found all over the third world countries, and have not been ameliorated since the incursion of liberal policies in mainstream political economy of Africa on the other hand, the World Bank sees poverty as a condition of life degraded by diseases deprivation and squalor (Olavononi 1997 in Ozughalu \& Ajayi 2003;513). Poverty in the absolute sense may be conceptualized as the inability of an individual or a general population to lack the ability to have access to the basic necessities as to warrant the attainment and maintenance of an objective minimum acceptable standard of living. Going by this definition how then does Africa look on this scale? Henriot (2002. www.unodo.org) posit that the least developed countries 1997 Report (UNCTAD) notes that 33 of the 48 LDCs are in Africa; that the continent has the highest debt to export ratio; that the average growth rate of these countries fell from $5.4 \%$ in 1995 to $4.6 \%$ in 1996; that the export of primary commodity prices fell especially in tropical foods. That aid flows have declined; that FDI flows have remained small.

He further contends that the SAP that brought about far reaching economic disruptions in Africa was driven by globalization. On the other hand Aluko-Olukun (2005:149-150) gives a graphic dismal picture of Africa's poverty condition which shows Africa "at the dawn of the new century with $12 \%$ of world's population. $1 \%$ of global energy consumption; $0.9 \%$ global FDIs less than $2 \%$ of global trade and export; most indebted region (foreign debt); $75 \%$ of the people infected with HIV/AIDS world wide". Amin (2003) has argued that; "poverty can then only be explained by causes decreed to be outside of economic logic, such as population growth or policy errors." He explains that the 'liberal virus' has deeply polluted contemporary social thought and has completely annihilated the capacity of the Western countries to understand the dynamics of the world, not to talk of generating any muscle to transform it. To Amin (2003) the only alternative is for developing nations, including Africa, to get rid of the liberal policies which he calls, "liberal virus" if they hope to run away from the prisons of ineffective corrective propositions, which by their very nature are only being generated by the progressive development of globalization.

Placing globalization as the point of departure in analyzing poverty issues in Africa without considering the question of poor leadership, corruption and the progressive destruction of our cultural ethos that have held us together even in the face of mounting underdevelopment of our economies in 1960s by African leaders is not adequate. Most African countries are blessed with abundant mineral and human resources but are on the other hand cursed with poor and ineffective leadership. African leaders blame the lack of development in African on globalization anchored on the policies of the advanced western countries for dominating the 
international economic system, but forget to understand that other countries in Africa and the third world who have faced similar challenges are still trudging ahead. For instance, Botswana and India have made significant strides in the area of economic stability and development by maintaining political stability and good governance (Aluko, 2003; Tule 2003; Uwatt 2003; Jike 2003).

\section{Globalization: Prospects And Challengs For Poverty Eradication And Development in Nigeria}

Globalization is capable of impacting both negatively and positively on a country's poverty level, as well as poverty eradication process. Khor (2005:9) states that:

Globalization is a very uneven process, with unequal distribution of benefits and losses. This imbalance leads to polarization between the few countries and groups that gain, and the many countries and groups in the society that lose out or are marginalized. Globalization, polarization, wealth concentration and marginalization are therefore linked through the same process.

Khor (2005:9) argues further that the process creates a focus for better opportunities in investment resources, growth and modern technology in a few countries in North-America, Europe, Japan and East Asian Newly industrializing countries (NICs). Invariably this process does not accommodate the majority of the developing countries who are also keen participants in the process. Thus it is capable of generating or accentuating poverty in these countries including Nigeria as well as hindering prospects of adopting workable poverty eradication strategies in Nigeria and elsewhere.

The consequences of free trade and unrestricted investment largely forced the fold up of firms in Nigeria and other poor African countries. Local enterprises could not compete with the massive imports leading to a process of "deindustrialization". Nigeria Textile industries have completely collapsed as a result of the influx of foreign textile products owing to the dictate of free trade and Nigeria's economic downturn. In zamfara (a state in Nigeria) for instance, Hariot (www.unido.org) reports that the once vibrant textile industry was hampered by influx of textile from Asia; several other industries such as tyre manufacture companies and medical supplies could not compete with South African products.

The cultural structure which sees integration of world cultures through the media is simply mesmerizing this has profound impact on the globalization process in Africa and Nigeria in particular. Through the global mass media, the internet, to channels like O, MTV, internet, etc presents a unique form of cultural imperialism. It gives the youth as well as the elders a new perception of the world around them, they cherish the foreign music, attitudes and values; rap music, hip-hop and the near nude - American syndrome is purely of Western style. Other attitudes such as homo-sexualism, lesbianism, etc are deriveds mainly from internet pornographic sites. These are harmful indeed. Otokhine (2002:2) in Akindele and others (2001:6) aver that there is a serious concern that nations like Nigeria whose contributions to the internet pool is low may lose their identity. He concludes that this sort of cultural imperialism enslaves the Nigerian mind and leaves him cultureless, or a culturally disoriented people. Nigeria, like countries of other regions have not faired better as a result of globalization. Africa particularly has been reported to have suffered from aggravated poverty as a result of the existing imbalances in growth across the world (Daors 2001; Wade 2001 calamsis 2001; Gondove 2001 in Akindele 2002). Thus tremendous and rising inequality is seen as a negative byproduct of globalization. The world Bank (2002) observed that globalization is exacerbating inequality (which means increasing disparities in poverty and wealth) and worsening the condition of the poor by eroding their incomes, increasing their vulnerability and adding to their disempowerment. This is so because, the richer countries with the requisite technology and capital increasingly cornering the dividends of globalization and Nigeria, and other African countries are not benefitting because they do not possess the "basic requirements for effective integration in the globalization process. These requirements include stable and growing economy, functional and efficient infrastructure, highly trained technical man power, supportive institutional capacity and good governance that is characterized by openness, accountability, probity and transparency" (Owolabi 1998) in Ozughah \& Ajayi 2003:511; Obioma and Osanyintuyi, 2004).

Khor (2005:20) opines that the globalization train has swept away policy autonomy of most countries as a result of the globalization of policymaking spearheaded by the Bretton Woods institutions and the WTO etc with the preponderance of global economic policy guidelines regulating international trade, etc. this is dangerous as it kills countries national policy initiatives and mechanism which are essential instruments for poverty eradication and development. Trade liberalization in a world which countries generally have different levels of technology, market and political strengthen creates problems for the weaker nations who hardly produce quantities or qualities that would compete at the global stag. The term of trade and prices of commodities also do not help matters as there is hardly any favorable arrangement. According to Khor (2005:18) "the terms of trade from non-fuel commodity vis a vis manufactures fell from 147 in 1980 to 100 in 1985 to 80 in 1980 and 71 in 1992. This shows 52 percent fall in terms of trade had catastrophic effects. Africa south of Sahara suffered more in this process as in four years 1986-1989, a whopping 56 billion income loss, or 
15-16 percent GDP in 1987-1989 (Khor 2005:18). This constitutes grave danger for the development of Africa and indeed the third world. The mechanism for the trade and financial control by WTO, IMF and World Bank is clearly leveraged by the G7 countries to the disadvantage of Africa and the world. For instance when trade is liberalized it is for who? When Nigeria has nothing in comparism to the great powers. It thus lead to what Khor (2005:19) refers to as "a vicious cycle of trade and balance of payment deficits, financial instability, and debt recession". The best option is for trade liberalization not to be pursued as if it is an "end in itself". First local industries must be revamped and repositioned for maximum output for them to be more productive and competitive only can liberalization of trade be feasible. Other challenges would be summarized as lack of appropriate response to debt crises and financial crises from Bretton Woods's institutions, World Bank and IMF which, instead of bailing debtor nations out, they attach structural adjustment policies with unconducive conditionalities that only deteriorated the economies of the recipient countries. An example is the SAP imposed in the 1980/90s during the Babangida administration which largely disrupted the Nigerian economy. Generally, there has been a perceived lack of transparency in international financial management by the major players. This has been the rationale for calls by the third world for a New International Economic Order, (NIECO) in the past (Aluko 2004, Khor 2005:51, Obadan 2004).

It is pertinent however to add that the globalization phenomenon has infected the intellectual focus of most third world scholars such that they are almost blinded from seeing the poor leadership and corruption behemoths that have strangulated their national economies. The impact of poor leadership and high level of corruption in some countries cannot assume even twenty percent in terms of the factors that are presently causing the underdevelopment and heightening poverty. The presence of the challenges of globalization should not overwhelm our approach to develop. On the political plane, globalization has reduced the political independence of nations in that to a large extent their sovereignty is impinged upon. The fact that multilateral policies and agreements must be adhered to by sovereign states without which sanctions are awarded amounts to political challenge. (Akindele, and others 2002). The question at this junction is what is responsible for the inability of African countries and other third world countries in meeting the basic requirements to reap the benefits of globalization? Why are other so-called third world nations such as the Asian Tigers - Malaysia, Indonesia, India, are able to brace up the challenges and meet up the requirements that have placed them on better stead to reap the benefits of globalization?

Contrary to the preponderance of opinion on the ills of globalization, many other scholars have in fact hailed the phenomenon as a useful tool for economic emancipation of Africa and especially Nigeria if well utilized. Kwanashie (1998); Egware (1998), and Aminat (2002), in Ozughalu and Ajayi (2003;510) opine that globalization has played important catalytic role in increasing economic growth and reducing absolute poverty in developing countries including Africa. They contend that globalization has led to better products, lower cost, job opportunities, increased productivity and improvement in global quality of welfare. Awoke (2002) in Ozughalu and Ajayi (2003:511) agree that " the average family in the world is said to have three times more income than it did 50 years ago". Globalization if well tamed is capable of generating employment and wealth generation in the areas of ICT. Education, health etc thereby adding to the overall GDP of African nations. Already the advent of the General Systems for Mobil Communication (GSM) have created millions of job opportunities in African nations such as Nigeria, Kenya, South Africa and Ghana, etc.

The issues of the ills of globalization on Nigeria and other third world nations in general have been pedestrianized by a section of third world scholarship, the political leaders and public affairs analyst. The abuse has generally blinded our view from the stack realities of poor and ineffective leadership in Africa and particularly Nigeria. Most of the third world nay African leaders crying wolf are mostly enmeshed in heightened corruption, "sit-tightism", creation of dual publics and ethnic divisions for selfish economic and political gains. These self-induced problems generate political instability which is antithetical to economic viability, growth and development. A comparative analysis of some African nations would indicate a disproportionate level of poverty and the attempts at eradicating it in order to put the nations on the right path for development. Contrary to the views held by many African scholars and their sympathizers that globalization cannot offer any tangible dividends to Africa, there are a lot of benefits that have accrued, and shall continue to accrue to Africa and Nigeria if they properly position themselves to grab the benefits of globalization.

\section{The Role Of Multinational Corporations}

Another important challenge arising from the fast globalizing world is the activities of the Multinational Corporation in Africa and indeed Nigeria as well as other developing countries. According to World Bank while global corporations have unquestionable brought greater wealth, power and opportunity to the poor world, especially china and India, some two billion people still live in countries or regions that have been left behind, becoming in fact less globalized. In these places trade has diminished in relation to national income, foreign investment and economic growth have stagnated, and poverty has risen. Most Africans were better off 40 years ago. The average per capita income of Muslims from Morocco to Bangladesh and beyond to 
Indonesia and the Philippines -is half the world average. Thus while globalization has benefited many, one-sixth of the world's people live in what the international finance corporation calls "deep poverty," as described in a 2004 speech by Peter Woicke, then IFC's executive vice president. Nigeria is not faring better with the presence of such multinational corporations. The practices of companies such as Cocoa Cola, Pepsi, shell petroleum, PZ, etc., leaves much to be desired when viewed within the framework of direct employment generation, and wealth creation. The practices of companies in the Niger Delta region of Nigeria have generated concerns for environmental degradation leading to militant agitations and total insecurity of the region in recent years. The repatriation of the huge profits by the multinational corporations leading to capital flight creates untold economic disruptions in the system. These corporations together form a clique that frustrates the emergence of viable industries that would compete with them. For instance, in Benue state, the assets of the Benue Bottling Company that came on board in the 1980s was successfully bought over by Cocoa Cola and Pepsi thus foreclosing the chances of revival of these industries in near future.

\section{How Nigeria Can Be Positioned To Reap The Gains Of Globalization}

At independence in 1960, Nigeria was largely a producer and net exporter of primary products. The six major agricultural products then were cocoa, rubber, palm oil, groundnut, cotton and palm kernel. Agricultural produce and raw material constituted the sole foreign exchange earner for the country. Specifically, the Nigerian state as an exporter of agricultural goods had $69.4 \%$ of its total GDP for the year 1963/64 comprising the six aforementioned agricultural commodities (Olaloku, 1979:8). At the discovery of oil and its subsequent displacement of agriculture main foreign earner for Nigeria in the early 1970s, Nigeria suddenly abandoned agriculture as a key factor economic growth and stability. From 1972 onward, oil gained ascendancy over commodities as the largest contributor to the GDP, and also as a major foreign exchange earner. There was substantial increase in oil production accompanied by a sharp increase in the global market price of high grade crude oil from low price of \$3.8 per barrel in October 1973 to a skyrocketing price of \$14.7 per barrel in January 1974. This trend continued till 1981 when the price of crude oil attained a high level of $\$ 38.77$ per barrel. Within the same period, total revenue from oil rose correspondingly from N1billion to N4billion while external reserves increased from N180million to N3.7billion in 1975 (Osaghae, 1998:96). The excessive reliance on oil export boom in 1970s, coupled with the non-diversification of the economy (i.e. through the poor development of the non-oil sector) rendered the Nigerian economy vulnerable to external shocks that later dislocated it. The windfall from oil led to tremendous rise in wage prices, imports and government expenditures.

The collapse of oil prices on the other hand has serious problems on budget and the economy. For instance in 1981/82, following the oil price collapse, rising inflation, currency devaluations, capital flight, high debt crisis and other domestic problem arose, making impracticable any effective budgetary projections in the firth place and when a budget is even made, its implementation to the later becomes problematic. A case in point is the recent projection made in the Nigerian budgets whereby the bench mark of crude oil sales is placed at $\$ 46$ per barrel, while even before the appropriation bill is yet to undergo scrutiny in the hands of the lawmakers, oil prices at the international market which were at an all-time high of about $\$ 145-\$ 147$ per barrel, to record an alltime low of $\$ 39$ per barrel early in the year. This shows that the success of Nigeria's budget predicated on $\$ 46$ per barrel of crude oil is no longer guaranteed. This is the danger arising from the dependence on a monoproduct in an economy. A similar thing occurred in 1998 as reported by Oyefusi 2007 that "the Nigerian government's budget of 1998 was based on the assumption of an average oil price of US\$17 per barrel but in the same month the budget was announced, the crude oil fell from about US\$16 to US\$14.73 per barrel, thus threatening the viability of the entire budget (News watch 16th February 1998, in Oyefusi 2007). The shocks and disruptions arising from market forces aside from the social and political issues affection the effective utilization of such a resource becomes problematic. These have been the challenges faced by the Nigerian economy over the decades when it abandoned agriculture and failed to develop the industrial sectors to compliment the oil sector in order to have a well-diversified economy that would ensure sustainable development of the country.

Nigeria must device and set in motion comprehensive development strategies/policies/programs to optimally position her economy to reap the dividends of globalization and eradicate poverty. But this suggestion may not go well with some scholars and leaders in Africa who often contend that it is not easy to make homegrown policies in the third world as long as the process of globalization is still hijacked and tailored to serve the interest of international capitalist enclave through the Bretton woods institutions the world bank, the IMF, WTO etc. to them these instruments of capitalism have hidden under the cloak of an otherwise natural globalizing process and have used it as a pure exploitative economic instrument against the third world countries by forcing on them repressive policies. But it should be emphasized that Nigeria cannot afford the luxury of wasting time on these problems. Nigeria must look at them as challenges to be overcome in order to enhance development. More often than not, it is the corrupt activities of internal collaborators that worsen the impact of external influence on third world economies. Homegrown policies at the regional, sub-regional and national front are 
imperative. Therefore homegrown economic policy formulation and strong commitment to their implementation and monitoring is the point of departure. The role of regional instrument under the auspices of the African Union (AU), Economic community to West African States (ECOWAS\}, East African Community etc. in the faithful commitment to achieving the Millennium Development Goals (MDGs) through strict adherence to the goals of New Partnership for Africa's Development (NEPAD) must be religiously to and emphasized. The Africa peer Review Mechanism (APRM) which is an initiative of the African Union is set up as a regional monitoring instrument is central to the realization of the goals that could ensure the collective realization of Africa's development agenda. Second, the chief actor pushing for free trade liberalization is WTO, which increasingly emerging as the instrument of the advanced countries. Their policies on trade and investment tend to favor the advanced countries of Europe and America to the detriment of Africa. To this end a political solution is apt. coordinated efforts to stand up to dominant outside forces that work for the detriment of the people must be keenly considered by all African leaders. But Nigeria must pioneer this initiative within the they should not gluttony swallow the policies churned out by these globalization agents without giving them home touch before applying them on the continent.

On the cultural plane, it is difficult if not possible to prevent the people of Nigerian from integrating with other countries through the ICT, cellular phones and the internet. The steps to take are enormous. Nigeria must develop her own media, ginger up the pool in the internet through competitive development of software solutions through the manufacture and launch of satellites in the orbit. We have several computer gurus that work in the ICT world in America. Nigerian born Philip Egwuamare is a good example. We can pay them just one tenth of what we pay our local government in Nigeria and they will develop our ICT to compete with the rest of the world. Nigeria must also put its house in order by ensuring best global democratic practices, good governance, probity and accountability so that the little resources accruing to her would be put to judicious use. Nigeria must not be rhetorical about her commitment to regional unity at the AU and other sub-regional groups. There is therefore the necessity for the country to diversify its economic base in order to confront the challenges of contemporary globalization process and remain relevant in the scheme of world events. The economies of south East Asian countries especially the Asian tigers namely; Taiwan, Hong Kong, Singapore and South Korea as well as Thailand, Malaysia and Vietnam are successful stories of how diversification has enhanced their economic developments. The success recorded by these newly industrialized countries (NIC) can be duplicated by Nigeria in its current efforts toward economic transformation.

There should also be an accelerated development of infrastructure such as transportation networks, electricity, water, telecommunication, health services and education to ensure economic security. Finally, the current attempt by the US government to bail out its ailing mortgage institutions and other finance houses and the private sector must be an eye opener to African states particularly Nigeria, who tend to accept completely the policies of deregulation and wholesale privatization without considering the micro-economic implications. They must learn to protect critical sectors of the economy such as agriculture, education and health sectors. Nigeria must ensure meaningful computer education at all levels of education; massive telecom infrastructures must be expanded throughout Nigeria to facilitate development. The advantages derivable from the internet and the GSM must be taken by Nigeria. Massive employments can be generated from these areas. Nigeria should launch her satellites to the orbit as a way of controlling what comes to her in terms of ICT. If her satellites are cheaper, their subscribers as well as broadcasters would take up the challenge and develop a good mass media which Jibo and Simbine (2003:15) have emphasized, would help to shape the psyche of the citizen thereby reshaping their attitudes that supports values of good governance, accountability and self-empowerment, which leads to poverty eradication and development. This would also check the negative impact of the western media as agents of positive change.

\section{Conclusion and Recommendations}

Globalization is akin to a jungle affair where the survival game is for the fittest alone. The north seems bereft of ideas to move capitalism to the next level, advances the idea of free trade and liberalization which is oiled by democracy and modernization of socio-cultural practices to pave the way for the complete engrailment of these concepts. A simple analogy would suffice at this juncture: in typical remote African villages where households are unfenced, the heads of such families do not over sleep; they take security measures which include good neighborliness and direct surveillance to wade-off imminent attacks. In a globalized world economy, leaders of African nations especially Nigeria have also take measures to safeguard against the negative challenges of a fast globalizing world system. Nigeria just like the rest of the developing world has to understand the world and its future direction with a view to taking it for necessary development and poverty eradication. For Nigeria to reap the gains of globalization it is recommended that she must embrace good governance, which incorporates political, economic and corporate components as a veritable culture for enhancing the benefits which any country can derive from globalization. 


\section{Reference:}

[1] Joseph Stiglitz (2002) Globalization and its Discontents. Great Britain; Allen Lane, the Penguin Press

[2] Adewuyi, A.O 'Can Nigeria Benefit from Globalization? Constraints, opportunities and challenges. Nigeria economic society, 2004

[3] Ake Claude (1996) Democracy and Development in Africa. Ibadan; Spectrum Books

[4] Ake claude (1996) A political Economic of Africa Ibadan, Longman.

[5] Akinboye,Solomon O "Globalization and the challenge for Nigeria's Development in 21stcentury" university of Lagos Nigeria.www.globalization.icaap.org/content.2008

[6] Akinbowo,O.L "Globalization, Information Technology and the Nigerian Financial System" Nigeria Economic Society,2004

[7] Akindele S.T, Gidado T.O \&Olaopo O.R "Globalization, its Implications and Consequences for Africa. http//www.unido.org/index.php?id.2002

[8] Aluko, Sam "Background to Globalization and Africa's Economic Development" Nigeria Economic Society, 2004

[9] Amin Samir "World Poverty Pauperization and Capital Accumulation” Monthly Review Vol.55, Number 5 ,2003

[10] Baylis J, \&Smith S, 2001 The Globalization of World Politics: An Introduction to International Relation New York, Oxford University Press

[11] George C. lodge Craig Wilson "Multinational Corporations-A Key To Global Poverty Reduction " yaleGlobal Online: http://yaleglobal. Yale.edu, 2006

[12] Henriot, P.J. "Globalization Implications for Africa". www.unido.org. 2002

[13] Jibo, M \& Simbine A. T. (2003) "The Nigerian Media: An Assessment of Its Role in Achieving Transparent and Accountable Government in the Fourth Republic" in Contemporary Issues in Nigerian Politics. Ibadan, Joded Publishers

[14] Jike, V.T "Globalization and the Crisis of African Development". The Nigerian Economic Society, 2004

[15] Khor, M (2005) Globalization and the South: Some Critical Issues, Ibadan, Spectrum Books Ltd.

[16] Obadan M.I "Globalization and Economic Management in Africa" The Nigerian Economic society" Nigeria Economic society, 2004.

[17] Obioma E.C and Osanyintuyi T. A "Globalization and economic growth in Nigeria: prospects and challenges "Nigeria Economic society,2004.

[18] Oboh, G.A.T. Globalization and competitiveness: Concept, Fears and Prospects for commonwealth countries “ UnionDigest, vol.9 Nos 324.December 2005.

[19] Offiong, Daniel A [1980] imperialism and Dependency: Obstacles to African Development Enugu, Fourth Dimension publishers

[20] Ojo,M.O “Globalization and Economic Development: international Experiences" Nigeria Economic society 2004.

[21] Olaloko, F.A (1979). Structure of the Nigerian Economy, London.

[22] Olomola P.A “Globalization, competition policy and Economic Development in sub Saharan Africa: opportunities and challenges. Nigerian Economic society .2004

[23] Onimode,Bade (2000) Africa in the World of the 21 Century. Ibadan University Press.

[24] Orubu C.O. and Awopegba P.O. "The Role of Good Governance in the Development Process in a Globalized World; Challenges for Nigerian Economy" Nigeria Economic Society. 2004

[25] Oyefusi, A. (2007) "Oil Dependence and Civil Conflict in Nigeria". CSAE WPS/2007_09

[26] Ozughalu U.M. and Ajayi P.I "Absolute poverty and Globalization: A Correlation: A Correlation of equity and Inequality. Nigeria Economic Society. 2004

[27] Stiglitz, J.E (2003) Globalization and Economic Discontents, New York, North and Co

[28] Todaro M. \&Smith, S.C (2003) Economic Development. Delhi, Pearson Education.

[29] Tule, Moses K "Globalization and Economic development of West Africa" Nigeria Economic Society, 2004.

[30] Uwatt, U.B. "Globalization and Economic Growth: the Africa Experience". Nigeria Economic Society, 2004. 